\title{
Pengaruh Intellectual Capital dan Corporate Social Responsibility terhadap Nilai Perusahaan dimoderasi oleh Kinerja
}

\author{
Rilla Gantino ${ }^{1^{*}}$, Leli Ruliati Alam ${ }^{2}$ \\ 1, 2Universitas Esa Unggul \\ rilla.gantino@esaunggul.ac.id \\ ${ }^{*}$ Penulis Korespondensi
}

\begin{abstract}
Increased performance will provide hope for investors and potential investors towards the company so that the company's value will increase, which is indicated by rising stock prices. This study aims to analyze the effect of intellectual capital and corporate social responsibility on firm value with company performance as a moderator variable in the basic and chemical industries listed on the Indonesia Stock Exchange (BEI) for the 2014-2018 period. Hypothesis testing results showed that simultaneous intellectual capital and corporate social responsibility affect the value of the company, partially intellectual capital affects the value of the company and financial performance succeeded in moderator the relationship between them, corporate social responsibility affects the company value, in addition simultaneously financial performance succeeded in moderator the relationship between intellectual capital and corporate social responsibility to the value of the company, partially financial performance succeeded in moderator the relationship between intellectual capital to the value of the company, while partially financial performance was not able to moderate the relationship between cororate social responsibility and corporate value.
\end{abstract}

Keywords: Intellectual Capital, Corporate Social Responsibility, Company Value and Financial Performance

\begin{abstract}
Abstrak
Kinerja yang meningkat akan memberikan harapan bagi investor dan calon investor terhadap perusahaan tersebut sehingga value perusahan akan meningkat yang ditandai dengan kenaikan harga saham. Penelitian ini bertujuan untuk menganalisis pengaruh intellectual capital dan corporate social responsibility terhadap nilai perusahaan dengan kinerja perusahaan sebagai variabel moderasi pada industri dasar dan kimia yang terdaftar di Bursa Efek Indonesia (BEI) periode 2014-2018. Hasil pengujian hipotesis menunjukan bahwa secara simultan intellectual capital dan corporate social responsibility berpengaruh terhadap nilai perusahaan, secara parsial intellectual capital berpengaruh terhadapn nilai perusahaan dan kinerja keuangan berhasil memoderasi hubungan keduanya, corporate social responsibiliy berpengaruh terhadap nilai perusahaan, selain itu secara simultan kinerja keuangan berhasil memoderasi hubungan antara intellectual capital dan corporate social resposibility terhadap nilai perusahaan, secara parsial kinerja keuangan berhasil memoderasi hubungan antara intellectual capital terhadap nilai perusahaan, sedangkan secara parsial kinerja keuangan tidak mampu memoderasi hubungan antara corporate social responsibility dan nilai perusahaan.
\end{abstract}

Kata kunci: Modal Intellectual, Corporate Social Responsibiliy, Nilai Perusahaan, Kinerja Perusahaan

\section{Cara Mengutip:}

Gantino, R., Alam, L.R. (2020). Pengaruh Intellectual Capital dan Corporate Social Responsibility terhadap Nilai Perusahaan dimoderasi oleh Kinerja. Esensi: Jurnal Bisnis dan Manajemen. Vol. 10 (2): 215-230. DOI: https://doi.org/10.15408/ess.v10i2.18858 


\section{PENDAHULUAN}

Pencapaian keberhasilan suatu perusahaan dapat diketahui melalui nilai perusahaan yang dapat dketahui melalui laporan keuangan. Nilai perusahaan didefinisikan sebagai persepsi penanam modal terhadap tingkat keberhasilan perusahaan yang sering dikaitkan dengan harga saham, serta dapat memberikan kesejahteraan bagi setiap investor apabila harga saham disebuah perusahaan semakin meningkat. Harga saham yang tinggi akan berdampak pada nilai perusahaan yang tinggi, sehingga meningkatkan kepercayaan pasar terhadap kinerja perusahaan saat ini serta pada prospek perusahaan dimasa mendatang (Harningsih et al., 2018).

Terdapat bebarapa penilaian kinerja perusahaan yang berhubungan dengan saham, yaitu dengan laba perlembar saham (earning per share), dividen perlembar saham (dividen per share), harga perlembar saham (price book value), nilai buku perlembar saham (book value pershare), diveiden payout ratio, price earning ratio, dan price to book value (Toto.S, 2012)

Apabila nilai perusahaan tinggi maka pasar akan percaya pada kinerja perusahaan serta prospek perusahaan di masa depan. Pada dasarnya investor mengukur kinerja perusahaan berdasarkan kemampuan perusahaan seperti kemampuan Profitabilitas (Puspitaningtyas, 2016). Untuk mempertahankan atau meningkatkan kinerjanya, perusahaan di tuntut agar bertahan pada persaingan yang semakin ketat, perusahaan akan melakukan berbagai upaya termasuk eksploitasi sumber daya alam dan sumber daya lainnya sehingga mengakibatkan kerusakan lingkungan alam dan akan berpengaruh kehidupan manusia. Untuk mengurangi dampak negatif terhadap kerusakan lingkungan, dilakukanlah corporate social responsibility (Agustina et al., 2015).

CSR awalnya bersifat suka rela dan kemudian pemerintah Indonesia Mengatur pelaksanaan CSR melalui UU no 40 tahun 2007 bersarkan pasal 74. corporate social responsibility saat ini bukan lagi bersifat sukarela yang dilakukan perusahaan didalam mempertanggung jawabkan kegiatan perusahaannya, melainkan bersifat wajib atau menjadi kewajiban bagi perusahaan menerapkannya. Kemudian ini diatur dalam Undang-Undang yang disahkan pada 20 Juli 2007, yaitu UU Nomor 40 Tahun 2007 Tentang Perseroan Terbatas (UU PT), Pasal 74 Undang-Undang Perseroan Terbatas menyatakan: (1) Perseroan yang menjalankan kegiatan usahanya di bidang dan/atau berkaitan dengan sumber daya alam wajib melaksanakan Tanggung Jawab Sosial dan Lingkungan (TJSL). (2) TJSL merupakan kewajiban Perseroan yang dianggarkan dan diperhitungkan sebagai biaya Perseroan yang pelaksanaannya dilakukan dengan memperhatikan kepatutan dan kewajaran. (3) Perseroan yang tidak melaksanakan kewajiban dikenai sanksi sesuai dengan ketentuan peraturan perundang-undangan.

Selain itu perusahaan juga akan berusaha secara maksimal untuk mencapai setiap tujuan yang telah direncanakan. Salah satu upaya untuk mencapai tujuan perusahaan adalah melalui peningkatan intellectual capital (IC) atau dikenal dengan modal intellectual. Perekonomian baru yang secara mendasar bergantung pada pengetahuan, keahlian dan informasi yang dimiliki perusahaan, juga merupakan upaya perusahaan dalam meningkatkan perhatian terhadap intellectual capital (Alipour, 2012).

Sesuai dengan Widyaningdyah (Widyaningdyah \& Aryani, 2013) yang menyatakan bahwa, suatu perusahaan dikatakan mempunyai keunggulan kompetitif jika dapat menciptakan nilai 
ekonomis yang lebih baik dibanding dengan perusahaan lain dalam industrinya. Berbeda dengan sebelumnya, saat ini fokus dunia bisnis tidak pada aset berwujud (tangible aset) namun sudah beralih ke aset tidak berwujud (Intangible asets). Kompetensi yang dimiliki karyawan, hubungan baik dengan pelanggan, penciptaan inovasi baru, sistem komputer dan administrasi yang uptodate, hingga kemampuan menguasai teknologi juga merupakan bagian dari intellectual capital (Soetedjo \& Safrina Mursida, 2014).

Penelitian mengenai pengaruh intellectual capital dan corporate social responsibility sudah banyak dilakukan peneliti sebelumya, antara lain oleh Gantino (Gantino et al., 2019a) menggunakan indikator ROA, ROE dan Pertumbuhan Penjualan sebagai indikator kinerja, hasil penelitian menyatakan intellectual capital berpengaruh positif signifikan terhadap ROA, ROE dan pertumbuhan penjualan pada sektor infrastcture, utilities and transportation dan pada sektor Basic Industries And Chemical. corporate social responsibility berpengaruh negatif terhadap ROA, berpengaruh positif signifikan terhadap ROE dan tidak signifikan terhadap pertumbuhan penjualan pada sektor Infrastcture, Utilities and Transportation sedangkan pada sektor basic industries and chemical menunjukkan corporate social responsibility berpengaruh negatif terhadap ROA, ROE dan pertumbuhan penjualan. Penelitian Sunarsih (Ni Made \& Ni Putu, 2019) menghasilkan bahwa IC dan CSR berpengaruh postif terhadap nilai perusahaan.

Penelitian sebelumnya dilakukan oleh Afis dan Eni (Badarudin \& Eni, 2018) menggunakan ROA sebagai indikator kinerja dan Tobins-Q untuk mengukur nilai perusahaan dengan menggunakan data 2013-2016 yang menghasilkan corporate social responsibility berpengaruh negatif terhadap nilai perusahaan, intellectual capital berpengaruh positif terhadap nilai perusahaan perusahaan. Kinerja keuangan tidak dapat memoderasi hubungan antara corporate social responsibility dengan nilai perusahaan namun kinerja keuangan dapat memoderasi hubungan antara intellectual capital dengan nilai perusahaan. Penelitian Adang (Adang, 2019) menyatakan bahwa corporate social respsonsibility berpengaruh terhadap nilai perusahaan. Namun penelitian Hendro (Sasongko et al., 2019) menyatakan bahwa CSR berpengaruh negative terhadap nilai perusahaan, demikian juga penelitian Stiaji (Stiaji et. al., 2017).

Penelitian lain dilakukan oleh Ramona (Ramona, 2017), meneliti pengaruh CSR terhadap Kinerja dengan menggunakan data tahun 2011-2015 dan hasil penelitiannya menunjukkan bahwa CSR tidak berpengaruh terhadap nilai perusahaan, dan profitabilitas tidak mampu memoderasi pengaruh CSR terhadap nilai perusahaan. Indikator yang digunakan untuk kinerja adalah ROA.

Selanjutnya Gantino (Gantino, 2016) melakukan penelitian pengaruh CSR terhadap kinerja mengguakan PBV, ROA dan ROE sebagai indikator kinerja dengan data tahun 20082014 dan menghasilkan bahwa CSR tidak berpengaruh terhadap PBV namun berpengaruh terhadap ROE dan ROA. Maharani (Maharani, 2014) melakukan penelitian pengaruh intellectual capital terhadap kinerja menggunakan data tahun 2011-2012 dan menggunakan ROA dan ATO sebagai indikator kinerja. Hasil penelitiannya menyatakan VAHU berpengaruh terhadap ROA dan STVA berpengaruh terhadap ATO.

Indikator Kinerja pada penelitian ini adalah ROA dan pengukuran nilai perusahaan menggunakan PBV dan menggunakan data dari laporan keuangan dan laporan keberlanjutan tahun 2014-2018, perusahaan di sektor industri dasar dan kimia.

Nilai intellectual capital yang tinggi mencerminkan perusahaan memiliki kualitas sumber 
daya manusia yang tinggi pula. Hal ini juga sesuai dengan penelitian Afis dan Eni (Badarudin \& Eni, 2018) menunjukan adanya hubungan positif antara IC dan nilai perusahaan demikian juga hasil penelitian Eristy (Utami, 2018), Nuryaman (Nuryaman, 2016).

Selanjutya penelitian Ramona (Ramona, 2017) dan Bawafi (Bawafi \& Prasetyo, 2015) menghasilkan bahwa corporate social responsibility berpengaruh positif terhadap nilai perusahaan, dimana dengan melakukan aktivitas CSR perusahaan dapat meningkatkan kepercayaan masyarakat terhadap produk perusahaan,sehingga reputasi perusahaan juga meningkat dimata masyarakat.

Intellectual capital dapat memberikan nilai lebih bagi perusahaan sehingga meningkatka daya saing. Banyak perusahaan masih beranggapan bahwa aset fisik berupa tanah, mesin, dan tenaga kerja yang dapat menghasilkan profit bagi perusahaan, sehingga fisik (intellectual capital) seperti, pengetahuan dan kompetensi karyawan, hubungan dengan pelanggan, inovasi, system computer dan administrasi, kreativitas dalam mendesain produk yang unik serta kemampuan menguasai teknologi (Hartati \& Hadiwidjaja, 2019).

Penelitian Ida (Ida et al., 2018) menghasilkan bahwa intellectual capital dan CSR berpengaruh terhadap nilai perusahaan, demikian pula penelitian Sunarsih (Ni Made \& Ni Putu, 2019)

$\mathrm{H}_{1}$ : Terdapat pengaruh intellectual capital dan corporate social responsibility terhadap nilai Perusahaan.

Hasil peneltian penelitian Afis dan Eni (Badarudin \& Eni, 2018), Eristy (Utami, 2018), serta penelitian Almira (Arifin \& Wahidahwati, 2018) dan sebelumnya Nuryaman (Nuryaman, 2016) menyatakan bahwa intellectual capital berpengaruh positif terhadap nilai perusahaan. Semakin tinggi intellectual capital yang dimiliki perusahaan maka semakin tinggi nilai perusahaan setelah penawaran umum saham perdana. Kondisi ini menunjukkan bahwa investor dapat menangkap sinyal yang diberikan oleh perusahaan melalui intellectual capital dan menggunakan informasi tersebut dalam analisis pembuatan keputusan investasi.

Pengungkapan modal intelektual berpengaruh positif secara signifikan terhadap nilai perusahaan. Perusahaan yang mengungkapkan lebih banyak komponen modal intelektual dalam laporan tahunannya cenderung memiliki nilai kapitalisasi pasar yang lebih tinggi. Sebelumnya hasil penelitian Ietje menyatakan bahwa pengungkapan modal intelektual yang makin tinggi akan memberikan informasi yang kredibel atau dapat dipercaya, dan akan mengurangi kesalahan investor dalam mengevaluasi harga saham perusahaan, sekaligus meningkatkan kapitalisasi pasar (Nazaruddin, 2014).

$\mathrm{H}_{2}$ : Terdapat pengaruh Intellectual Capital terhadap Nilai Perusahaan.

Penelitian Ramona (Ramona, 2017) dan Bawafi (Bawafi \& Prasetyo, 2015) menghasilkan bahwa corporate social responsibility berpengaruh positif terhadap nilai perusahaan, dimana dengan melakukan aktivitas CSR perusahaan dapat meningkatkan kepercayaan masyarakat terhadap produk perusahaan,sehingga reputasi perusahaan juga meningkat dimata masyarakat. Hal ini berarti semakin tinggi pengungkapan CSR, maka semakin tinggi nilai perusahaan. Perusahaan yang membangun hubungan baik dengan stakeholder dengan melaksanakan aktivitas CSR akan meningkatkan reputasi perusahaan dimata investor sehingga dapat meningkatkan nilai saham perusahaan

Semakin baik perusahaan melak(Dyah \& Satyawan, 2019)ukan pengungkapan akan 
terbangun citra perusahaan yang makin baik di masyarakat akan mempunyai pandangan yang bagus karena kepentingan umum. Aktititas CSR dapat menjadi elemen yang perusahaan, memberikan kontribusi kepada manajemen risiko dan memelihara hubungan yang dapat memberikan keuntungan jangka panjang bagi perusahaan. CSR memberikan kontribusi bagi perusahaan menciptakan laba yang berdampak dari loyalitas konsumen atas produk dan jasa yang ditawarkan perusahaan (Prastuti \& Budiasih, 2019).

$\mathrm{H}_{3}$ : Terdapat pengaruh corporate social responsibility terhadap nilai perusahaan

Semakin berkualitas intellectual capital yang dimiliki perusahaan maka semakin berkualitas pula sumber daya manusia yang dimiliki perusahaan. Sumber daya manusia yang berkualitas akan memudahkan perusahaan mencapai kinerja keuangan yang baik sehingga nilai perusahaan juga ikut naik, karena itu intellectual capital juga dapat meningkatkan nilai perusahaan kepada pemegang saham (Badarudin \& Eni, 2018).

Pada hasil penelitian Nurhayati (Nurhayati, 2017) menunjukkan bahwa modal intellectual berpengaruh positif pada kinerja keuangan. Temuan penelitian ini meng-indikasikan bahwa semakin efisien perusahaan mengelola sumber daya intellectual (physical capital, human capital dan structural capital) yang dimiliki perusahaan akan memberikan hasil yang meningkat yang ditunjukkan dari peningkatan kinerja keuangan perusahaan. Demikian pula penelitian Gunawan (Gunawan \& Putranto, 2017).

Kinerja suatu perusahaan akan bergantung pada suatu penciptaan transformasi dan kapitalisasi dari pengetahuan perusahan itu sendiri atau biasa dikenal dengan intellectual capital. Sehingga intellectual capital memiliki pengaruh terhadap ROA (Agustina et al., 2015). Perusahaan yang mampu mengelola sumber daya intelektual yang dimilikinya dengan efektif dan efisien, maka kinerja keuangannya akan meningkat.

Corporate social responsibility (CSR) mempengaruhi kinerja keuangan. Secara teori CSR seharusnya dapat menjadi pertimbangan investor sebelum berinvestasi, karena didalamnya mengandung informasi sosial yang telah dilakukan perusahaan. Dengan pelaporan dan pengungkapan CSR, para stakeholder dapat mengevaluasi bagaimana pelaksanaan CSR dan memberikan penghargaan/sanksi terhadap perusahaan sesuai hasil. Sehingga IC, dan CSR memiliki pengaruh secara bersama-sama terhadap kinerja keuangan perusahaan evaluasinya.

Hasil penelitian Mirwan (Mirwan, 2018) menyatakan bahwa intellectual capitan dan corporate social responsibility berpengaruh terhadap nilai perusahaan dimoderasi oleh kinerja. Namun bertentangan dengan hasil penelitian afis (Badarudin \& Eni, 2018)

$\mathrm{H}_{4}$ : Terdapat pengaruh intellectual capital dan corporate social responsibility terhadap nilai perusahaan dengan kinerja keuangan sebagai pemoderasi

Penelitian Afis dan Eni (Badarudin \& Eni, 2018) menyatakan bahwa Kinerja keuangan dapat memoderasi hubungan antara intellectual capital dengan nilai perusahaan. Demikian pula hasil penelitian Lestari (Dyah \& Satyawan, 2019). Intellectual capital menunjukkan aset berupa pengetahuan sumber daya manusia yang dimiliki oleh perusahaan. Memiliki sumber daya manusia yang berkualitas akan mendorong tercapainya kinerja keuangan perusahaan yang tinggi juga, sehingga dapat meningkatkan nilai perusahaan.

$\mathrm{H}_{5}$ : Terdapat pengaruh Intelectual Capital terhadap Nilai Perusahaan dengan kinerja keuangan sebagai pemoderasi. 
Corporate social responsibility (CSR) berpengaruh positif signifikan terhadap kinerja keuangan perusahaan yang diproksikan dengan return on assets (ROA), hal ini menunjukkan bahwa semakin banyak pengungkapan aktivitas tanggung jawab sosial perusahaan dalam laporan tahunan perusahaan akan semakin meningkatkan kinerja keuangan perusahaan (Bhernadha et al., 2017).

Bawafi (Bawafi \& Prasetyo, 2015) menyatakan bahwa kinerja keuangan dapat memoderasi pengaruh tanggung jawab sosial perusahaan dengan nilai perusahaan. Semakin tinggi kinerja keuangan perusahaan akan menjadikan kegiatan sosial yang dilakukan perusahaan semakin banyak. Oleh karena itu corporate social responsibility akan meningkatkan nilai perusahaan pada saat kinerja keuangan perusahaanmeningkat.

Menurut Gantino (Gantino, 2016) corporate social responsibility (CSR) berpengaruh terhadap variabel kinerja keuangan perusahaan, hasil yang sama dinyatakan oleh Ludfi (Ludfi \& Firdausi, 2017) dan Winnie (Parengkuan, 2017) serta Gantino (Gantino et al., 2019) dengan indikator ROE.

$\mathrm{H}_{6}$ : Terdapat pengaruh corporate social responsibility terhadap Nilai Perusahaan dengan kinerja keuangan sebagai pemoderasi.

\section{METODE}

Penelitian ini merupakan penelitian kawsalitas yaitu penelitian dengan bertujuan untuk mengetahui pengaruh atau hubungan antara dua variabel atau lebih. Penelitian ini bertujuan untuk menguji pengaruh variabel independen yaitu intelectual capital dan corporate social responsibility terhadap variabel dependen yaitu price book value serta pengaruh return on asset (ROA) dalam memoderasi hubungan keduanya. Jenis data yang digunakan dalam penelitian ini adalah data sekunder yang diperoleh dari BEI atau www.idx.co.id. Sedangkan data yang digunakan penelitian ini adalah laporan tahunan perusahaan untuk periode 20142018 pada perusahaan industri dasar dan kimia yang terdaftar di BEI.

Variabel yang digunakan dalam penelitian ini terdiri dari variabel dependen, variabel independen, dan variabel moderating.

Tabel 1. Tabel Oprasional Variabel

\begin{tabular}{lcc}
\hline \multicolumn{1}{c}{ Variabel } & Proksi & Skala \\
\hline 1. Intellectual Capital $\left(\mathrm{VAIC}^{\mathrm{TM}}\right)$ & VAIC $^{\mathrm{TM}}=\mathrm{VACA}+$ VAHU + STVA & Rasio \\
\hline 2. Corporate Social Responsibility $(\mathrm{CSR})$ & $\boldsymbol{C S D I j}=\frac{\sum \boldsymbol{X} i j}{\boldsymbol{n} j}$ & Rasio \\
\hline 3. Nilai Perusahaan & $\boldsymbol{P B V}=\frac{\text { Price pershare }}{\text { Book value pershare }}$ & Rasio \\
\hline 4. Kinerja Perusahaan & $\mathbf{R O A}=\frac{\text { Earning After Tax (EAT) }}{\text { Total Assets (Total Aktiva) }} \boldsymbol{x} \mathbf{1 0 0} \%$ & Rasio \\
\hline
\end{tabular}

Metode dan teknik analisis data yang dilakukan dalam penelitian ini adalah dengan analisis statistik dengan menggunakan perangkat lunak statistik. Alat analisis data yang digunakan adalah statistik deskriptif, yakni untuk mendeskripsikan variabel-variabel dalam penelitian ini. 
Analisis data dilakukan dengan bantuan perangkat lunak SPSS (Statistic Package for Social Science), selanjutnya teknik analisis yang di gunakan yaitu, analisis statistik deskriptif, Uji asumsi klasik yang terdiri dari uji normalitas, uji multikolinieritas, uji heteroskedastisitas, uji autokorelasi, setelah melakukan uji asumsi klasik dilakukan analisis regresi berganda, pengujian hipotesis yang terdiri dari, uji $\mathrm{F}$ (Simultan), uji signifikansi parsial (t-test), uji koefisien determinasi (uji adjusted $\mathrm{R}^{2}$ ), dan setelah melakukan pengujian hipotesis untuk mengetahui pengaruh variabel pemoderasi dalam memperkuat atau memperlemah hubungan, dilakukan uji interaksi atau yang sering disebut dengan moderated regression analysis (MRA).

\section{HASIL DAN PEMBAHASAN}

\section{Analisis Regresi Berganda}

Melalui Pengujian dan analisis terhadap pengembangan hipotesis terhadap hubungan variabel independen dan variabel dependen. Maka di peroleh hasil dari analisis regresi linear berganda sebagai berikut:

Tabel 2 Hasil Uji Regresi Berganda

\begin{tabular}{|c|c|c|c|c|c|c|c|c|}
\hline \multicolumn{9}{|c|}{ Coefficients $^{\mathrm{a}}$} \\
\hline & \multirow{2}{*}{ Model } & \multicolumn{2}{|c|}{$\begin{array}{l}\text { Unstandardized } \\
\text { Coefficients }\end{array}$} & \multirow{2}{*}{$\begin{array}{c}\begin{array}{c}\text { Standardized } \\
\text { Coefficients }\end{array} \\
\text { Beta }\end{array}$} & \multirow{2}{*}{$\mathbf{t}$} & \multirow{2}{*}{ Sig. } & \multicolumn{2}{|c|}{ Collinearity Statistics } \\
\hline & & B & Std. Error & & & & Tolerance & VIF \\
\hline \multirow[t]{4}{*}{1} & (Constant) & -.033 & .205 & & -.159 & .874 & & \\
\hline & LN_X1 & .197 & .070 & .192 & 2.836 & .005 & .999 & 1.001 \\
\hline & LN_X2 & .408 & .135 & .209 & 3.031 & .003 & .968 & 1.033 \\
\hline & LN_Z & .229 & .044 & .355 & 5.150 & .000 & .968 & 1.033 \\
\hline
\end{tabular}

a. Dependent Variable: LN_Y

Sumber: Hasil olah data

Berdasarkan tabel 7 yang dapat dilihat pada tabel, diperoleh nilai konstanta sebesar 0,033 , nilai $\beta 1$ sebesar 0.197 , nilai $\beta 20,408$ dan $\beta 3$ sebesar 0,229 . Dengan demikian dapat dibentuk persamaan linear berganda sebagai berikut:

$$
Y=-0,033+0,197 X 1+0,408 X 2+0,229 Z
$$

\section{Uji Hipotesis}

Penelitian ini bertujuan untuk menganalisis pengaruh antara variabel independen yaitu intelectual capital dan corporate social responsibility terhadap variabel dependen yaitu price book value, sebelum dilakukan pemoderasian oleh variabel moderator yaitu return on assets.

\section{Uji F ( Uji Simultan)}

Uji statistik F digunakan untuk mengetahui kelayakan data. Uji statistik F menunjukkan apakah semua variabel bebas yang dimasukkan dalam model mempunyai pengaruh secara bersama-sama terhadap variabel dependen, hasil dari uji simultan dapat dilihat pada tabel berikut: 
Tabel 3 Hasil Uji F (Simultan)

\begin{tabular}{ccccccc}
\multicolumn{7}{c}{ ANOVA $^{\mathrm{a}}$} \\
& Model & Sum of Squares & df & Mean Square & F & Sig. \\
\hline \multirow{2}{*}{1} & Regression & 39.768 & 3 & 13.256 & 17.171 & $.000^{\mathrm{b}}$ \\
& Residual & 128.155 & 166 & .772 & & \\
& Total & 167.923 & 169 & & & \\
\hline
\end{tabular}

a. Dependent Variable: LN_Y

b. Predictors: (Constanta), LN_Z, LN_X1, LN_X2

Sumber: Hasil olah data

Tabel 3 diperoleh nilai F hitung sebesar 17.171 dan nilai signifikansi F hitung sebesar 0,000, yaitu nilai signifikansi lebih kecil dari 0,05, dimana hal ini menunjukkan bahwa Ha1 diterima yang artinya bahwa terdapat pengaruh intellectual capital, dan corporate sosial responsibility secara simultan terhadap nilai perusahaan.

Resource-Based Theory menyebutkan bahwa keunggulan kompetitif perusahaan diperoleh dari kemampuan perusahaan untuk merakit dan memanfaatkan kombinasi sumber daya yang tepat, sumber daya yang tepat dan dapat memberikan keunggulan kompetitif, serta kinerja yang berkelanjutan. Hal ini sejalan dengan konsep intellectual capital yang kemudian kesejahteraan sumber daya manusia yang terdapat dalam perusahaan termasuk dalam tanggung jawab sosial dan lingkungan (corporate social responsibility).

Hasil uji yang dilakukan membuktikan bahwa intellectual capital, dan corporate social responsibility berpengaruh terhadap nilai perusahaan pada perusahaan industri dasar dan kimia, Penelitian ini sejalan dengan penelitian Ida (Ida et al., 2018) menghasilkan bahwa intellectual capital dan CSR berpengaruh terhadap nilai perusahaan, demikian pula penelitian Sunarsih (Ni Made \& Ni Putu, 2019).

Pengujian statistik secara parsial melalui T-test dilakukan untuk membuktikan signifikansinya terhadap pengaruh variabel independen secara individu dalam mempengaruhi variabel dependen. Melalui tingkat signifikansi sebesar 5\%, hasil dari uji parsial dapat di lihat pada tabel berikut:

Tabel 4 Hasil Uji Signifikansi Parsial (t-test)

\begin{tabular}{|c|c|c|c|c|c|c|c|c|}
\hline \multicolumn{9}{|c|}{ Coefficients $^{a}$} \\
\hline & \multirow{2}{*}{ Model } & \multicolumn{2}{|c|}{$\begin{array}{l}\text { Unstandardized } \\
\text { Coefficients }\end{array}$} & \multirow{2}{*}{$\begin{array}{c}\begin{array}{c}\text { Standardized } \\
\text { Coefficients }\end{array} \\
\text { Beta }\end{array}$} & \multirow[t]{2}{*}{ t } & \multirow{2}{*}{ Sig. } & \multicolumn{2}{|c|}{ Collinearity Statistics } \\
\hline & & B & Std. Error & & & & Tolerance & VIF \\
\hline \multirow[t]{4}{*}{1} & (Constant) & -.033 & .205 & & -.159 & .874 & & \\
\hline & LN_X1 & .197 & .070 & .192 & 2.836 & .005 & .999 & 1.001 \\
\hline & LN_X2 & .408 & .135 & .209 & 3.031 & .003 & .968 & 1.033 \\
\hline & LN_Z & .229 & .044 & .355 & 5.150 & .000 & .968 & 1.033 \\
\hline
\end{tabular}

a. Dependent Variable: LN_Y

Berdasarkan tabel 4 diperoleh nilai t hitung sebesar 2,836 dan nilai signifikansi $\mathrm{t}$ hitung sebesar 0,005 yaitu nilai signifikansi lebih kecil dari 0,05. Hal ini menunjukkan 
bahwa $\mathrm{Ho}_{2}$ ditolak dan $\mathrm{Ha}_{2}$ diterima yang artinya terdapat pengaruh intellectual capital secara parsial terhadap nilai perusahaan. Sesuai dengan teori sinyal (signaling teory) yang menyatakan perusahaan akan berusaha secara maksimal untuk mencapai setiap tujuan yang telah direncanakan. Salah satu upaya dalam pencapaian tujuan perusahaan adalah peningkatan intellectual capital atau dikenal dengan modal intelektual agar investor tertarik untuk menanamkan modalnya yang berdampak dengan naiknya nilai perusahaan. Penelitian ini di dukung oleh penelitian Nuryaman (Nuryaman, 2016), Adang (Adang, 2019)

Hasil penelitian ini tidak mendukung penelitian Aditya (Aditya \& Sudarno, 2014), Ida (Ida et al., 2018) dan (Dyah \& Satyawan, 2019) serta penelitian Lestari menghasilkan bahwa intellectual capital memiliki pengaruh negatif dan signifikan terhadap nilai perusahaan. Hasil penelitian yang berbeda dari hasil penelitian ini adalah hasil penelitian Eristy (Utami, 2018) menghasilkan bahwa VACA, VAHU berpengaruh terhadap nilaai perusahaan namun STVA tidak berpengaruh terhadap nilai perusahaan, tahun sebelumnya hasil yang sama diperoleh dari penelitian Wulan (Wahyuni et al., 2017).

Berdasarkan tabel 4 diperoleh nilai t hitung sebesar 0,031 dan nilai signifikansi $t$ hitung sebesar 0,003 yaitu nilai signifikansi lebih kecil dari 0,05. Hal ini menunjukkan bahwa $\mathrm{Ho}_{3}$ ditolak dan $\mathrm{Ha}_{3}$ diterima yang artinya terdapat pengaruh corporate social responsibility secara parsial terhadap nilai perusahaan.

Hasil pengujian yang dilakukan membuktikan adanya hubungan positif antara corporate social responsibility dengan nilai perusahaan, hal ini dikarenakan jumlah pengungkapan corporate social responsibility yang tinggi menunjukkan bahwa perusahaan telah melakukan tanggung jawabnya secara sosialnya terhadap masyarakat sekitar dengan baik. Oleh karena itu corporate social responsibility dapat meningkatkan nilai perusahaan baik di mata investror maupun di mata masyarakat sekitar. Hasil penelitian ini sejalan dengan Bawafi (Bawafi \& Prasetyo, 2015), Fauzia (Fauzia \& Amanah, 2016), Hu (Hu et al., 2018) Chun (Chung et al., 2018),. Sedangkan hasil penelitian dari Yustisia Puspaningrum (2014), Suci Ramona (2017), Stiaji (Stiaji et. al., 2017), Sasogko (Sasongko et al., 2019) dan Nuryana (Nuryana \& Bhebhe, 2019) menyatakan hal sebaliknya bahwa corporate social responsibility tidak berpengaruh terhadap nilai perusahaan serta penelitian Adang (Adang, 2019) yang menyatakan bahwa CSR berpengaruh negative terhadap nilai perusahaan.

Tujuan dari pengujian ini adalah untuk mengetahui seberapa besar variabel independen mampu mempengaruhi dan dapat menjelaskan variabel dependennya dalam persamaan yang dibuat secara cermat. Penilaian terhadap adjusted $R^{2}$ dengan interval dimulai dari angka 0 sampai 1 .

Tabel 5 Hasil Uji Koefisien Determinasi

Model Summary

\begin{tabular}{|c|c|c|c|c|c|c|c|c|c|c|}
\hline \multirow[b]{2}{*}{ Model } & \multirow[b]{2}{*}{$\mathbf{R}$} & \multirow[b]{2}{*}{$\mathbf{R}^{2}$} & \multirow{2}{*}{$\begin{array}{l}\text { Adjusted } \\
\text { R Square }\end{array}$} & \multirow{2}{*}{$\begin{array}{l}\text { Std. Error } \\
\text { of the } \\
\text { Estimate }\end{array}$} & \multicolumn{5}{|c|}{ Change Statistics } & \multirow{2}{*}{$\begin{array}{l}\text { Durbin- } \\
\text { Watson }\end{array}$} \\
\hline & & & & & $\begin{array}{l}\text { R Square } \\
\text { Change }\end{array}$ & F Change & df1 & df2 & $\begin{array}{l}\text { Sig. F } \\
\text { Change }\end{array}$ & \\
\hline 1 &, $487^{\mathrm{a}}$ &, 237 & ,223 & ,87864 & ,237 & 17,171 & 3 & 166 & ,000 & 1,859 \\
\hline
\end{tabular}

Sumber: Hasil olah data 
Hasil perhitungan pada table 10, diketahui nilai Adjusted $R$ Square sebesar 0,223 hal ini diartikan bahwa sebesar 22,3\% variabel dependen price book value dipengaruhi variabel independent yaitu intellectual capital dan corporate social responsibility. Sedangkan sisanya sebesar $77,7 \%$ dijelaskan oleh faktor-faktor lain.

Uji interaksi atau yang sering disebut dengan Moderated Regression Analysis (MRA) merupakan aplikasi khusus regresi berganda liner di mana dalam persamaan regresinya mengandung unsur interaksi dengan mengalikan variabel independen dengan variabel moderasi.

Tabel 6 Hasil Uji Interaksi secara Simultan

\begin{tabular}{ccccccc}
\hline \multicolumn{7}{c}{ ANOVA $^{\mathrm{a}}$} \\
\multicolumn{1}{c}{ Model } & Sum of Squares & Df & Mean Square & F & Sig. \\
\hline 1 & Regression & 21.010 & 2 & 10.505 & 11.943 & $.000^{\mathrm{b}}$ \\
& Residual & 146.894 & 167 & .880 & & \\
\cline { 3 - 6 } & Total & 167.904 & 169 & & & \\
\hline
\end{tabular}

a. Dependent Variable: LN_Y

b. Predictors: (Constant), LN_X2.Z, LN_X1.Z

Sumber: Hasil olah data

Pengujian hipotesis 4: pengaruh intellectual capital, dan corporate sosial responsibility secara simultan terhadap nilai perusahaan dengan kinerja keuangan sebagai variabel moderasi

Tabel 6 diperoleh nilai F hitung sebesar 11,943 dan nilai signifikansi F hitung sebesar 0,000, yaitu nilai signifikansi lebih kecil dari 0,05, dimana hal ini menunjukkan bahwa $\mathrm{Ha}_{4}$ diterima yang artinya bahwa terdapat pengaruh intellectual capital, dan corporate sosial responsibility secara simultan terhadap nilai perusahaan dengan kinerja keuangan sebagai variabel moderasi.

Secara teoritis sumber daya yang dimiliki perusahaan berpengaruh terhadap kinerja perusahaan yang pada akhirnya akan meningkatkan nilai perusahaan. Salah satu sumber daya yang dimiliki oleh perusahaan dari aset tidak berwujud yang diungkapkan adalah intellectual capital, sehingga pengungkapan modal intelektual sebagai sebuah sumber daya yang dimiliki oleh perusahaan berpengaruh terhadap kinerja perusahaan yang pada akhirnya akan meningkatkan nilai perusahaan, yang salah satunya dapat dilihat dari harga saham perusahaan

Berdasarkan uji interaksi (analisis regresi moderasi) hasil uji $\mathrm{F}$ menunjukan bahwa intellectual capital, dan corporate social responsibility secara bersama-sama (simultan) berpengaruh terhadap nilai perusahaan dengan kinerja keuangan sebagai variabel modearating. yang artinya hipotesis keempat diterima, namun kinerja keuangan memperlemah hubungan antara intellectual capital dan corporate sosial responsibility terhadap nilai perusahaan, hal ini di buktikan dengan hasil uji $\mathrm{F}$ sebelum dan setelah di lakukan pemoderasi.

Return on asset memperlemah hubungan ketiganya secara simultan. Hal ini dikarenakan kinerja keuangan pada industri dasar dan kimia yang sangat berfluktuasi dibuktikan dengan hasil uji statistik deskriptif dengan nilai standar deviasi yang cukup tinggi di banding variabel lainnnya. Selain itu yang menjadi penilaian investor dalam berinvestasi adalah industri ini 
memang memiliki peluang laba yang besar dan sama besarnya dengan resiko yang dimiliki karena produk hasil dari industri dasar dan kimia dapat digunakan oleh industri lainnya.

Hasil pengujian yang dilakukan membuktikan bahwa intelectual capital dan corporate social responsibility secara bersama-sama berhasil mempengaruhi nilai perusahaan dengan kinerja keuangan sebagai variabel moderasi, hal ini mendukung hasil penelitian Mirwan (Mirwan, 2018) dan bertentangan dengan hasil penelitian dari Afis dan Eni (2013)

Tabel 7 Hasil Uji Interaksi secara Parsial

\begin{tabular}{|c|c|c|c|c|c|c|c|c|}
\hline \multicolumn{9}{|c|}{ Coefficients $^{\mathrm{a}}$} \\
\hline & \multirow{2}{*}{ Model } & \multicolumn{2}{|c|}{$\begin{array}{l}\text { Unstandardized } \\
\text { Coefficients }\end{array}$} & \multirow{2}{*}{$\begin{array}{c}\begin{array}{c}\text { Standardized } \\
\text { Coefficients }\end{array} \\
\text { Beta }\end{array}$} & \multirow{2}{*}{$\mathbf{t}$} & \multirow{2}{*}{ Sig. } & \multicolumn{2}{|c|}{ Collinearity Statistics } \\
\hline & & B & $\begin{array}{l}\text { Std. } \\
\text { Error }\end{array}$ & & & & Tolerance & VIF \\
\hline \multirow[t]{3}{*}{1} & (Constant) & -.198 & .080 & & -2.467 & .015 & & \\
\hline & LN_X1.Z & .118 & .034 & .361 & 3.479 & .001 & .487 & 2.054 \\
\hline & LN_X2.Z & .005 & .049 & .010 & .097 & .923 & .487 & 2.054 \\
\hline
\end{tabular}

a. Dependent Variable: LN_Y

Sumber: Hasil olah data

Pengujian hipotesis 5: pengaruh intellectual capital secara parsial terhadap nilai perusahaan dengan kinerja keuangan sebagai variabel. Berdasarkan tabel 7, diperoleh nilai $t$ hitung sebesar 3,479 dan nilai signifikansi t hitung sebesar 0,001 yaitu nilai signifikansi lebih kecil dari 0,05. Hal ini menunjukkan bahwa $\mathrm{Ho}_{5}$ ditolak dan $\mathrm{Ha}_{5}$ diterima yang berartinya terdapat pengaruh intellectual capital secara parsial terhadap nilai perusahaan dengan kinerja keuangan sebagai variabel moderasi.

Nilai coefficients $\beta$ sebelum dilakukan uji interaksi sebesar 0,197 dan Nilai coefficients $\beta$ setelah dilakukan uji interaksi sebesar 0,118 yang artinya kinerja keuangan sebagai berhasil memoderasi dengan cara memperlemah hubungan antara intellectual capital dan nilai perusahaan, karena nilai coefficients $\beta$ sebelum dimoderasi lebih besar di bandingkan setelah dimoderasi. Kinerja keuangan yang diukur menggunakan return on asstes berhasil menjadi mediasiantara hubungan intellectual capital terhadap nilai perusahaan. dampak yang diberikan variabel moderator yaitu kinerja keuangan terhadap pengaruh antara intellectual capital terhadap nilai perusahaan adalah memperlemah pengaruh antara intellectual capital terhadap nilai perusahaan.

Hasil pengujian pada penelitian ini menunjukan bahwa kinerja keuangan sebagai berhasil memoderasi dengan cara memperlemah hubungan antara intellectual capital dan nilai perusahaan, hal ini dikarenakan kinerja keuangan pada industri dasar dan kimia yang sangat berfluktuasi dibuktikn dengan hasil uji statistik deskriptif dengan nilai standar deviasi yang cukup tinggi di banding variabel lainnnya. Selain itu yang menjadi penilaian investor dalam berinvestasi adalah industri ini memang memiliki peluang laba yang besar dan sama besarnya dengan resiko yang dimiliki karena produk hasil dari industri dasar dan kimia dapat digunakan oleh industri lainnya. 
Penelitian ini didukung oleh hasil penelitian Ramona (Ramona, 2017) dan penelitian Afis dan Eni (Badarudin \& Eni, 2018) dan bertentangan dengan penelitian Mirwan (Mirwan, 2018).

Pengujian hipotesis 6: pengaruh corporate social responsibility secara parsial terhadap nilai perusahaan dengan kinerja keuangan sebagai variabel moderasi: Berdasarkan tabel 7 diperoleh nilai t hitung sebesar 0,097 dan nilai signifikansi t hitung sebesar 0,923 yaitu nilai signifikansi lebih besar dari 0,05. Hal ini menunjukkan bahwa $\mathrm{Ho}_{6}$ diterima dan $\mathrm{Ha}_{6}$ ditolak yang artinya tidak terdapat pengaruh corporate social responsibility secara parsial terhadap nilai perusahaan dengan kinerja keuangan sebagai variabel moderasi. Hasil penelitian ini bertentangan dengan hasil penelitian Bawafi (Bawafi \& Prasetyo, 2015) dan Nuryana (Nuryana \& Bhebhe, 2019) dan mendukung penelitian Afis dan Eni (Badarudin \& Eni, 2018).

Perkembangan konsep CSR berjalan seiring dengan berkembangnya konsep stakeholder. Beberapa pengamat bisnis menyarankan kepada komunitas bisnis untuk menggunakan kekuasaan dan pengaruhnya untuk tujuan-tujuan sosial yang lebih luas, tidak hanya sekedar untuk memaksimalkan keuntungan perusahaan, Secara teoritis kinerja keuangan dapat memperkuat atau memperlemah hubungan antara pengaruh corporate social responsibility terhadap nilai perusahaan, hal ini dikarenakan semakin tinggi kinerja keuangan perusahaan akan membuat kegiatan sosial yang dilakukan perusahaan semakin banyak. Oleh karena itu corporate social responsibility akan meningkatkan nilai perusahaan pada saat kinerja keuangan perusahaan meningkat.

Pada kenyataannya kinerja keuangan yang di proksikan dengan return on asset tidak dapat memperkuat atau memperlemah pengaruh corporate social responsibility sebab pengungkapan corporate social responsibility tetap mempengaruhi nilai perusahaan walau kinerja perusahaan naik atau turun. Investor mempertimbangan aspek jangka panjang melalui pengungkapan corpoarate social responsibility, Investor juga mengharapkan agar perusahaan tetap bertanggung jawab pada lingkungan dan sosial yang dipengaruhi oleh kegiatan oprasional perusahaan, walaupun kinerja perusahaan meningkat atau menurun, kegiatan corporate sosial responsibility harus tetap dilaksanakan untuk kepentingan jangka panjang perusahaan sehingga nilai perusahaan akan meningkat.

Kinerja keuangan tidak dapat memperkuat atau memperlemah hubungan antara corporate social responsibility dengan nilai perusahaan, hal ini dikarenakan sudut padang investor yang mengangap bahwa kegiatan corporate social responsibility tetap harus berjalan walaupun kinerja keuangan naik atau turun, yang selanjutnya di dukung oleh peraturan pemerintah Indonesia tentang pelaksanaan corporate social responsibility melalui UU no 40 tahun 2007 bersarkan pasal 74.

Corporate social responsibility saat ini bukan lagi bersifat sukarela yang dilakukan perusahaan didalam mempertanggung jawabkan kegiatan perusahaannya, melainkan bersifat wajib atau menjadi kewajiban bagi perusahaan menerapkannya.Yang kemudian diatur dalam Undang-Undang yang disahkan pada 20 Juli 2007, yaitu UU Nomor 40 Tahun 2007 Tentang Perseroan Terbatas (UU PT), Pasal 74 Undang-Undang Perseroan Terbatas menyatakan: (1) Perseroan yang menjalankan kegiatan usahanya di bidang dan/atau berkaitan dengan sumber daya alam wajib melaksanakan Tanggung Jawab Sosial dan Lingkungan (TJSL). (2) TJSL merupakan kewajiban Perseroan yang dianggarkan dan diperhitungkan sebagai biaya 
Perseroan yang pelaksanaannya dilakukan dengan memperhatikan kepatutan dan kewajaran. (3) Perseroan yang tidak melaksanakan kewajiban dikenai sanksi sesuai dengan ketentuan

\section{SIMPULAN}

Penelitian ini bertujuan untuk mengetahui pengaruh variabel intellectual capital, dan corporate sosial responsibility terhadap nilai perusahaan dengan kinerja keuangan sebagai variabel moderasi pada perusahaan industri dasar dan kimia yang terdaftar di Bursa Efek Indonesia periode 2014-2018.

Berdasarkan hasil penelitian seperti yang telah diuraikan di bab sebelumnya, maka dapat disimpulkan bhwa intellectual capital, dan corporate sosial responsibility secara bersamasama berpengaruh terhadap nilai perusahaan, terdapat pengaruh dari intellectual capital, terhadap nilai perusahaan, terdapat pengaruh dari variabel corporate sosial responsibility terhadap nilai perusahaan. Selanjutnya penelitian ini membuktikan intellectual capital, dan corporate sosial responsibility secara bersama-sama berpengaruh terhadap nilai perusahaan dengan kinerja keuangan sebagai pemoderasi, terdapat pengaruh dari intellectual capital, terhadap nilai perusahaan dengan kinerja keuangan sebagai pemoderasi dan membuktikan tidak terdapat pengaruh dari variabel corporate sosial responsibility terhadap nilai perusahaan dengan kinerja keuangan sebagai pemoderasi.

\section{PUSTAKA ACUAN}

Adang, F. (2019). Pengaruh Intellectual Capital, Corporate Social Responsibility, dan Sales Growth Terhadap Firm Value. Jurnal Bina Akuntansi, 6(1), 48-75.

Aditya, E. L., \& Sudarno. (2014). Hubungan Intellectual Capital, Kinerja Keuangan Dan Nilai Perusahaan Saat Ipo. Diponegoro Journal of Accounting, 3(2), 1-9.

Agustina, W., Yuniarta, G. A., \& Sinarwati, N. K. (2015). Pengaruh Intelectual Capital, Corporate Social Responsibility Dan Good Corporate Governance Terhadap Kinerja Keuangan (Studi Kasus Pada Perusahaan BUMN yang Terdaftar di Bursa Efek Indonesia Pada Tahun 2011-2013). E-Journal S1 Ak Universitas Pendidikan Ganesha, 3(1).

Alipour, M. (2012). The effect of intellectual capital on firm performance: an investigation of Iran Insurance Companies. Measuring Business Excellence, 16(1), 53-66. Https:// Doi.Org/10.1108/13683041211204671\&Hl=Id\&Sa=T\&Oi=Qabs-View\&Ct= Res\& $\mathrm{D}=14559901393750175572 \&$ Ei=9rvmxiq0ema-Ygtvlal4ba\& Qabs=1 \&At=The+ Effect+Of+Intellectual+Capital+On+Firm+Performance:+An+Investigation+Of ...

Arifin, A. F., \& Wahidahwati. (2018). Pengaruh Intellectual Capital Dan Csr Terhadap Nilai Perusahaan Dengan Gcg Sebagai Pemediasi. Jurnal Ilmu Dan Riset Akuntansi, 7(6).

Ayub, I. I. (2017). Buku Corporate Social Responsibility In The Digital Era. Deepublish,Yogyakarta.

Badarudin, A., \& Eni, W. (2018). Pengaruh Corporate Social Responsibility Dan Intellectual Capital Terhadap Nilai Perusahaan Dengan Kinerja Keuangan Sebagai Variabel Moderasi. AKUNESA, 6(2), 1-26.

Baroroh, N. (2013). Analisis Pengaruh Modal Intelektual terhadap Kinerja Keuangan Perusahaan BUMN yang Go Public. Jurnal Dinamika AkuntansilM), 5(2), 172-182. 
Bawafi, M. H., \& Prasetyo, A. (2015). terhadap Nilai Perusahaan dengan Profitabilitas sebagai Variabel Pemoderasi. Jurnal Reviu Akuntansi Dan Keuangan, 5(1), 721-730.

Bhernadha, Y., Topowijono, T., \& Azizah, D. (2017). Pengaruh Corporate Social Responsibility Terhadap Kinerja Keuangan Perusahaan (Studi Pada Perusahaan Winner Of Sustainability Reporting Award (Sra) 2015 Yang Terdaftar Di Pt Bei Periode 2010-2014). Jurnal Administrasi Bisnis S1 Universitas Brawijaya, 44(1), 134-143.

Chung, C. Y., Jung, S., \& Young, J. (2018). Do CSR Activities Increase Firm Value? Evidence from the Korean Market. Sustainability, 10, 1-22. https://doi.org/10.3390/su10093164

Dyah, A. D. L., \& Satyawan, M. D. (2019). Pengaruh Intellectual Capital Terhadap Nilai Perusahaan Dengan Profitabilitas Sebagai Variabel Moderasi. Jurnal Mahasiswa Universitas Negeri Surabaya, 1-22.

Eliana Saragih, A. (2017). Pengaruh Intelektual capital (Human capital, Struktural capital dan Costumer Capital) terhadap kinerja perusahaan manufaktur yang terdaftar di bursa efek Indonesia. Jrak, 3(1492141026), 1-56.

Fauzia, N., \& Amanah, L. (2016). Pengaruh Intellectual Capital, Karakteristik Perusahaan, Dan Corporate Social Responsibility Terhadap Nilai Perusahaan. Jurnal Ilmu Dan Riset Akuntansi., 5(.), 1-22.

Febriana, E., Djumahir, \& Achmad, H. D. (2016). Kepemilikan Saham Manajerial dan Profitabilitas Terhadap Nilai Perusahaan ( Studi pada Perusahaan Manufaktur yang Terdaftar di BEI Pada 2011-2013 ). Jurnal Ekonomi Bisnis Tahun, 21(2).

Gantino, R. (2016). Pengaruh Corporate Social Responsibility Terhadap Kinerja Keuangan Perusahaan Manufaktur yang Terdaftar di Bursa Efek Indonesia periode 2008-2014. Jurnal Dinamika Akuntansi Dan Bisnis, 3(2), 19-32. https://doi.org/10.17969/jdab.v3i2.5384

Gantino, R., Ruswanti, E., \& Rahman, T. (2019a). Leadership Style, Intellectual Capital, Corporate Social Responsibility and Corporate Performance: A Compara-tive study between two Indonesian Industries. Journal of Accounting Research, 2(3), 90-97. www/http/jurnal. unsyiah.ac.id/JAROE

Gantino, R., Ruswanti, E., \& Rahman, T. (2019b). Leadership Style, Intellectual Capital, Corporate Social Responsibility and Corporate Performance: A Compara-tive study between two Indonesian Industries. Journal of Accounting Research Organization and Economics, 2(3), 90-97. www/http/jurnal.unsyiah.ac.id/JAROE

Gunawan, A., \& Putranto, Y. A. (2017). Pengaruh Intellectual Capital Terhadap Kinerja Keuangan Dengan Barriers To Entry Sebagai Variabel Mediasi. JURNAL NOMINAL, 6(2), 48-63.

Harningsih, S., Agustin, H. \&, \& Setiawan, M. A. (2018). Pengaruh Kinerja Keuangan Terhadap Nilai Perusahaan Dengan Pengungkapan Csr Dan Kebijakan Dividen Sebagai Variabel Moderasi. Journal of Multidisciplinary Research And Development.

Hartati, N., \& Hadiwidjaja, R. D. (2019). The Value Relevance of Intellectual Capital and Ownership Structure on the SMEs Performance. Jurnal Organisasi Dan Manajemen, 15(2), 194-205. https://doi.org/10.33830/jom.v15i2.705.2019

Hu, Y., Chen, S., Shao, Y., \& Gao, S. (2018). CSR and Firm Value: Evidence from China. Sustainability, 10(12), 1-18. https://doi.org/10.3390/su10124597 
Ida, S., Nurkholis, \& Endang, M. (2018). Intellectual Capital Disclosure On Firm Value. Jurnal Aplikasi Manajemen, 16(1), 125-135.

Irham, F. (2012). Introduction to Financial Management (Pengantar Manajemen Keuangan). Bandung : Alfabeta.

Julmi, A. M. (2017). Faktor-Faktor Yang Mempengaruhi Kelengkapan Pengungkapan Laporan Keuangan Pada Perusahaan Manufaktur Yang Terdaftar Di Bei Tahun 2011-2013. JOM Fekon, 4(1), 1051-1065.

Laurensia, T., Saarce, S., Hatane, E., Bisnis, A., \& Kristen, U. (2015). Pengaruh Intellectual Capital Dalam Kinerja Keuangan Dan Nilai Perusahaan ( Studi Empirik Pada Perusahaan Industri Sektor Konsumsi Yang Go Public Di Bursa Efek Indonesia Tahun 2008-2012). BUSINESS ACCOUNTING REVIEW, 3(1), 33-44.

Ludfi, R., \& Firdausi, I. (2017). Pengaruh Corporate Social Responsibility Terhadap Kinerja Keuangan. Jurnal Penelitian Ilmu Ekonomi, 7, 39-47.

Maharani, G. P. (2014). Analisis Pengaruhmodal Intelektual Terhadap Kinerja Keuangan Perusahaan BUMN Yang Go Public. Jurnal Mahasiswa Universitas Negeri Surabaya, 2(1), 198.

Mirwan, A. R. (2018). Firm Value Creation Through Intellectual Capital And Corporate Social Performance With Mediated Of Financial Performance Using Islamic Manufacturing Sector As Supplementary Analysis. RJOAS, 8(90), 97-103.

Nazaruddin, G. A. S. \& I. (2014). Pengaruh Modal Intelektual dan Pengungkapannya Terhadap Nilai dan Kinerja Perusahaan. JURNAL AKUNTANSI \& INVESTASI, 15(2).

Ni Made, S., \& Ni Putu, D. S. (2019). The Effect Of Intellectual Capital And Corporate Social Responsibility On Firm Value. Proceedings of the 3rd International Conference of Project Management (ICPM) Bali.

Nurhayati, S. (2017). Analisa Pengaruh Intellectual Capital Terhadap Kinerja Pasar Dan Kinerja Keuangan Pada Perusahaan LQ45 Yang Terdaftar Di Bursa Efek Indonesia Periode Tahun 2010-2013. JURNAL ASET (AKUNTANSI RISET), 9(1), 133-172.

Nuryaman. (2016). The Influence of Intellectual Capital on The Firm 's Value with The Financial Performance as Intervening Variable The Influence of Intellectual Capital on The Firm 's Value with The Financial Performance as Intervening Variable. Social and Behavioral Sciences, 292 - 298. https://doi.org/10.1016/j.sbspro.2015.11.037

Nuryana, I., \& Bhebhe, E. (2019). Pengungkapan Corporate Social Responsibility Terhadap Nilai Perusahaan Dengan Profitabilitas Sebagai Variabel Moderating. AFRE Accounting and Financial Review, 2(2), 142-146.

Parengkuan, W. E. (2017). Pengaruh Corporate Social Responsibility ( Csr ) Terhadap Kinerja Keuangan Perusahaan Manufaktur Yang Terdaftar Di Bursa Efek Indonesia Melalui Pojok Bursa FEB - UNSRAT The Influence of Corporate Social Responsibility ( CSR ) to Manufacture Financial Perf. Jurnal EMBA, 5(2), 564-571.

Prastuti, M. C., \& Budiasih, I. G. A. N. (2019). E-Jurnal Akuntansi Universitas Udayana Pengaruh Corporate Social Responsibility dan Intellectual Capital Pada Kinerja Keuangan Fakultas Ekonomi dan Bisnis Universitas Udayana ( Unud ), Bali, Indonesia PENDAHULUAN 
Kinerja keuangan menjadi faktor utama dan. E-Jurnal Akuntansi Universitas Udayana, 27(2), 1365-1393.

Puspitaningtyas, A. (2016). Pengaruh Earning Per Share, Price To Book Value, Tingkat Inflasi, Dan Nilai Kurs Dollar Terhadap Harga Saham Perusahaan Sub Sektor Industri Otomotif Dan Komponennya Di Bursa Efek Indonesia . Manajemen Bisnis Krisnadwipayana, 4(1). Ramona, S. (2017). Artikel Ilmiah Pengaruh Corporate Social Responsibility Terhadap Nilai Perusahaan. Jurnal Mahasiswa Prodi Akuntansi, 3(1).

Sasongko, H., Alipudin, A., \& Uria, M. Y. (2019). Effect Corporate Social Responsibility, Firm Size, and Intellectual Capital on Firm Value in Indonesia Stock Exchange. International Journal of Latest Engineering and Management Research (IJLEMR), 04(06), 78-89.

Setyarini, S. (2012). Pengaruh Modal Intelektual dan Pengungkapannya Terhadap Kinerja Perusahaan. Jurnal Akuntansi Dan Keuangan, 14(1), 16-31. https://doi.org/10.18196/ JAI-2015.0035

Soetedjo, S., \& Safrina Mursida. (2014). Pengaruh Intellectual Capital Terhadap KinerjaKeuangan Pada Perusahaan Perbankan. Simposium Nasional Akuntansi XVII.

Stiaji et. al. (2017). Pengaruh Corporate Social Responsibility terhadap Nilai Perusahaan dengan Profitabilitas sebagai Variabel Moderating. Jurnal Riset Akuntansi, [Online], 6(6).

Syahirah, C. S., \& Lantania, M. F. (2016). Pengaruh Market Value Added, Economic Value Added, Kebijakan Dividen Dan Kepemilikan Manajerial Terhadap Nilai Perusahaan Pada Perusahaan Manufaktur Yang Terdaftar Di Bursa Efek Indonesia Tahun 20102014. Jurnal Ilmiah Mahasiswa Ekonomi Akuntansi, 1(1).

Toto.S. (2012). Memahami Laporan Keuangan. PPM.

Utami, E. M. (2018). The Intellectual Capital Components on Firm Value: Evidence from LQ-45 Index Companies. Jurnal Keuangan Dan Perbankan, 22(2), 291-300.

Wahyuni, W., Anwar, C., \& Sutratno. (2017). Pengaruh Intellectual Capital Terhadap Nilai Perusahaan Dengan Free Cash Flow Sebagai Variabel Moderating ( Studi Empiris Pada Perusahaan Manufaktur Secondary Sectors di Bursa Efek Indonesia). Jurnal Ilmiah IlmuEkonomi, 6(11), 61-73.

Widyaningdyah, A. U., \& Aryani, Y. A. (2013). Intellectual Capital dan Keunggulan Kompetitif (Studi Empiris Perusahaan Manufaktur versi Jakarta Stock Industrial Classification- JASICA). Jurnal Akuntansi Dan Keuangan, 15(1), 1-14. https://doi.org/10.9744/jak.15.1.1-14 